\title{
J(ब)
}

\begin{tabular}{||l||c||c||}
\hline \hline Received 19.10.2021 & & JOTS \\
$6 / 1$ \\
\hline \hline Accepted 06.12.2021 & Review & $2022: 214-220$ \\
\hline \hline Published 01.01.2022 & & \\
\hline
\end{tabular}

\section{Böler, T. Türkiye Türkçesi Ses Bilgisi, İstanbul: Kesit Yayınlar1, 2021, ss. 296. ISBN: 978-605-7898-80-7}

\author{
Ayşe ERYILMAZ* \\ Düzce University (Düzce/Turkey) \\ E-mail: ayseeryilmaz.4119@gmail.com
}

Tanıtımını yapacağımız Tuncay Böler'in eseri son beş yıl içerisinde ses bilgisi alanında kaleme alınan eserler arasında yer almaktadır. Esere yazarın kısa bir biyografisi ile giriş yapılmıştır. Biyografide (s. 6) yazarın hayatı ve diğer eserleri hakkında bilgi verilmiştir. Eserin devamında İçindekiler (s. 7-14) bölümü, Sunuş (s. 15-16) bölümü ve Kısaltmalar ve Isşaretler (s. 17-18) bölümü yer almaktadır. Hazırlıklarına hâlâ devam edilen Türkiye Türkçesi Dil Bilgisi dizesi hakkında bilgi verilerek ve eserin bu dize içerisindeki yerine değinilerek Sunuş bölümüne başlanılmıştır.

Ses bilgisinin diğer dil bilgisi alanlarıyla kısa bir mukayesesi yapıldıktan sonra eserin hazırlanış aşamalarından ve bu aşamada karşılaşılan bazı sorunlardan bahsedilmektedir. Kısaltmalar ve İşaretler bölümünde ise eserde kullanılan işaretler ve kısaltmalar hakkında bilgi verilmiştir.

Dil Bilgisi (s. 19-24) çalışmanın ilk bölümüdür. Bölümde dil bilgisi türleri ile alt dalları incelenmiştir. Genel Dil Bilgisi ve Özel Dil Bilgisi dil bilgisi türü olarak, Ses Bilgisi/Fonetik, Biçim Bilgisi/Morfoloji, Sözdizimi/Sentaks, Anlam Bilgisi/Semantik, Sözlük Bilgisi/Leksikoloji, Lehçe Bilgisi/Diyalektoloji ve Köken Bilgisi/Etimoloji de dil bilgisi alt dalları olarak ele alınmış ve terim anlamlarıyla açıklanmıştır. Türkçenin Ses Bilgisine Dair Bazı Temel Kaynaklar alt başlı̆̆ında da dil bilgisi ile ilgili kırk altı çalışmanın bibliyografik künyesine yer verilmiştir.

ORCID ID: 0000-0003-0265-414X. 


\section{J(ఠ)}

Ses Bilgisi (s. 25-54) bölümünde ses bilgisinin alt başl1kları olan Söyleyiş Ses Bilgisi, Akustik Ses Bilgisi ve İşitsel Ses Bilgisi hakkında bilgi verilmiştir. Ses, Ses Organları, Harf ve Alfabe ile IPA alt başlıklar halinde açıklanmıştır. Uluslararası Ses Abecesi başlığında seslerin çıkış yerleriyle ilgili bilgiler verilmiş ve tablolarla görselleştirilmiştir. Ses birim ve parçalı ses birim terimleri açıllanmıştır. Türkçe'nin Sesleri (s. 29-47) başlı̆̆ında Ünlüler ve Ünsüzler ele alınmıştır. Ünlüler (s. 29-39) kısmı, Dudakların Durumu Bakımından Ünlüler, Alt Çenenin Durumu Bakımından Ünlüler, Dilin Durumu Bakımından Ünlüler ve Çıkış Süresi Bakımından Ünlüler şeklinde alt başlıklara ayrılarak aşağıdaki gibi sınıflandırılmış ve örneklendirilmiştir:

Ünlüler

Dudakların Durumu Bakımından Ünlüler

Düz Ünlü: a, e, 1, i

Yuvarlak Ünlü: o, ö, u, ü

Alt Çenenin Durumu Bakımından Ünlüler

Geniş Ünlü: a, e, o, ö

Dar Ünlü: 1, i, u, ü

Dilin Durumu Bakımından Ünlüler

Ön Ünlü: e, i, ö, ü

Art Ünlü: a, 1, o, u

Çıkış Süresi Bakımından Ünlüler

Uzun Ünlü: AT āt 'ad', AT tô̄rt ‘dört', /söle-/ < söyle-

Kısa Ünlü: yllan < llan, sttma < isttma

Ünsüzler (s. 39-47), ise Boğumlanma Noktaları Bakımından Ünsüzler, Titreşim Bakımından Ünsüzler, Süreklilik ve Süreksizlik Bakımından Ünsüzler, Ağız ya da Burun Karşıtlığı Bakımından Ünsüzler ve Yarı Ünlü şeklinde alt başlıklara ayrılarak aşağıdaki gibi sınıflandırılmıştır:

Ünsüzler

Boğumlanma Noktaları Bakımından Ünsüzler

Çift Dudak Ünsüzleri: /b/, /m/, /p/

Diş Ünsüzleri: /d/, /n/, /s/, /t/, /z/

Diş-Dudak Ünsüzleri: /f/, /v/ 


\section{0}

Diş Eti-Damak Ünsüzleri: /c/, /ç/, /j/, /ş/

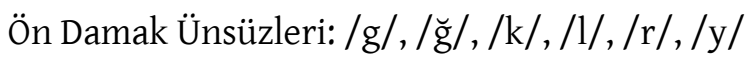

Art Damak Ünsüzleri: /g/, / $\breve{g} /, / \mathrm{k} /$

Grrtlak Ünsüzü: /h/

Titreşim Bakımından Ünsüzler

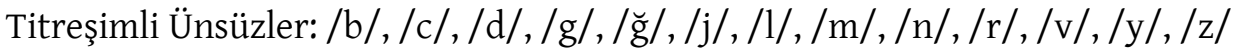

Titreşimsiz Ünsüzler: /ç/, /f/, /h/, /k/, /p/, /s/, /ş/,/t/

Süreklilik ve Süreksizlik Bakımından Ünsüzler

Sürekli Ünsüzler: /f/, /ğ/, /h/, /j/, /l/, /m/, /n/, /r/,/s/, /ş/, /v/, /y/, /z/

Süreksiz Ünsüzler: /b/, /c/, /ç/, /d/, /g/, /k/, /p/,/t/

Ağız ya da Burun Karşıtlığı Bakımından Ünsüzler

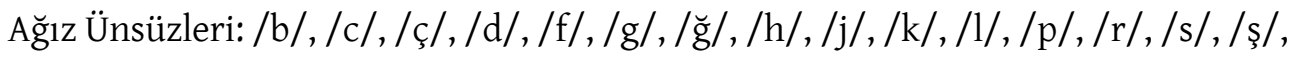
/t/, /v/, /y/, /z/

Burun (Geniz) Ünsüzleri: /m/, /n/

Yarı Ünlü: / $\breve{g} /, / y /$

Ünsüzlerin Sinıflandırılmasındaki Farklliklar başlığında bu konudaki mevcut bakış açılarına değinilmiştir. Bölümün son altı sayfasında (s. 49-54) alanyazına ait bazı çalışmalardan elde edilen bilgiler tablo şeklinde görselleştirilmiştir.

Türkçenin Ses Özellikleri (s. 55-84) bölümü Türkçenin Ünlüler Bakımından Ses Özellikleri ve Türkçenin Ünsüzler Bakımından Ses Özellikleri şeklinde ikiye ayrılmış ve çeşitli eserlerden elde dilen örneklerle açıklanmıştır. Ses Bilgisel Çözümleme Örnekleri alt başlı̆̆ında (s.78-83) ise Şevket Rado'nun Eşref Saati eserinden alıntılanan "Filozof diyor ki: 'Yaşama zevkinden ne kastettiğini anlamanin en kısa yolu insanların nasıl yemek yediklerine, daha doğrusu yemekler karşısında aldıkları vaziyete bakmaktır." cümlesindeki sözcükler incelenmiştir. Aşağıda örnek olarak verilen filozof sözcügü bu incelemelerden bir tanesidir:

Filozof

Türkçe değildir.

Türkçede /f/ ünsüzü bulunmaz.

Türkçede /o/ ünlüsü ilk hecede bulunabilir. 
Sözcükte artlık-önlük uyumu (büyük ünlü uyumu) ve düzlük-yuvarlaklık uyumu (küçük ünlü uyumu) yoktur.

Sözcük Fransızcadan [TT filozof < Fr. philosophe] dilimize geçmiştir.

Cümledeki diğer sözcüklerin de filozof sözcüğü gibi ses bilgisinin yanı sıra biçim bilgisi ve köken bilgisi açısından da incelenmiş olmaları okuyucunun dil bilgisi hâkimiyetini olumlu yönde etkilemektedir.

Ses Dizimi (s. 85-101) bölümü Ses Uyumları ve Seslerin Birleşmesi şeklinde ikiye ayrılmıştır. Ses uyumları Ünlü Uyumu, Ünsüz Uyumu ve Ünlü-Ünsüz Uyumu olmak üzere üç tanedir. Söylem esnasında dilin ve dudağın durumuna bağlı olarak belirlenen Ünlü Uyumları, Artlık-Önlük Uyumu ve Düzlük-Yuvarlaklık Uyumu şeklinde ikiye ayrılmıştır. Ünsüz Uyumu söylem esnasındaki titreşim özelliğine dayalıdır ve titreşimli-titreşimli veya titreşimsiz-titreşimsiz şeklinde olduğu belirtilmiştir. Boğumlanma noktaları açısından hem ön damak hem de art damak ünsüzü olan /k/, /g/ ve / g/ ses birimin sözcüklerde ön damak-ön damak veya art damak-art damak şeklinde yer almasının da Ünlü-Ünsüz Uyumu olduğu ifade edilmiştir. İncelenen eserlerden elde edilen örnekler faklı diller ile fonetik açıdan karşılaştırılmış ve seslerin bir araya gelişi değerlendirilmiştir.

Seslerin Birleşmesi başlı̆̆ında ise Türkçedeki hece/seslem çeşitleri Bir Ünlü ile Kurulan Heceler, Ünlü + Ünsüz Biçimindeki Heceler, Ünsüz + Ünlü Biçimindeki Heceler, Ünsüz + Ünlü + Ünsüz Biçimindeki Heceler, Ünlü + Ünsüz + Ünsüz Biçimindeki Heceler ve Ünsüz + Ünlü + Ünsüz + Ünsüz Biçimindeki Heceler şeklinde alt başliklara ayrılıp örneklendirilmiştir.

Ses Olayları (s. 102-270) bölümü eser içerisindeki en kapsamlı bölümdür. Ses olaylarının tanımı ve açıklaması ile giriş yapıldıktan sonra eş zamanlı ve art zamanlı incelemeye uygun örnekler verilmiştir. Ön seste, iç seste ve son seste gerçekleşen ses olayları ile ilgili örnekler verilirken standart dilin yanı sıra konuşma dilinden ve ağılardan da yararlanılmıștır Ses olaylarının sınıflandırılması ile ilgili alanyazındaki görüş farklılıklarına değinilmiştir. Ünlülerle İlgili Ses Olaylar, Ünsüzlerle İlgili Ses Olayları ve Ünlü-Ünsüzlerle İlgili Ses Olayları şeklinde üç ana başlığa ayrılan ses olayları aşağıdaki gibi sınıflandırılmış ve alt başlıklara ayrılmıştır:

Ses Olayları

Ünlülerle İlgili Ses Olayları 


\section{J(O)}

Türeme ve Düşme: TT istop < İng. stop (türeme), yanlşs < yanıllş (düşme)

Ünlü Değişmeleri

Önlüleşme: TT bünye < Ar. bunye

Artlılaşma: /barabar/ < beraber

Daralma:/gelmiyen/< gelmeyen

Genişleme:/çağar-/<çă̆ır-

Yuvarlaklaşma: /sabur/ < sabır

Düzleşme: TT çarşı < Far. çār+sū

Kısalma: TT hayat < Ar. hayāt

Uzama: /dōru/ < doğru

Ünlü Çatışması: şiir, saat

Ünlü Kaynaşması: nasıl < ne asıl, şura < şu ara

Ünsüzlerle İlgili Ses Olayları

Türeme ve Düşme: TT mavi < Ar. mäāi (türeme), getir-< keltür- (düşme)

Ünsüz Değişmeleri

Ünsüz Tekleşmesi: TT kasap < Ar. kașșāb

Ünsüz İkizleşmesi:/eşşik/<eşik

Titreşimlileşme: /berşembe/ < perşembe

Titreşimsizleşme:/çatır/ < çadır

Akıcılaşma: /beyen-/< beğen-

Sızıcılaşma: TT hoşaf < Far. hুoş $+\bar{a} b$

Patlayıcılaşma: /çarçaf/ < çarşaf

Ağızsılaşma: /soğra, soyra/ < soñra

Burunsulaşma:/mayram/< bayram

Dudaksıllaşma: kambur < kanbur

Ünsüz Kaynaşması: sabıña < sabınga, batsıkıña < batsıkınga

Ünsüz Ayrışması: /dengiz/ < deñiz, /sanga/ < saña

Ünlü-Ünsüzlerle İlgili Ses Olayları

Göçüşme: TT çeyrek < Far. çār+yek, TT mintan < Far. nīm+ten

Benzeşme: /günnük/ < günlük, pembe < penbe 
Aykırılaşma: TT aktar < Ar. 'atțar, TT tandır < Far. tennūr

Hece Düşmesi: öğleyin < öğleleyin

Büzülme: /müdāle/ < müdahale, /kāt / < kâğıt

Yukarıda sadece birkaç tanesine yer verilen ses olaylarıyla ilgili örnekler, art zamanlı incelemelerde, alıntı sözcüklerde, standart dilde, konuşma dilinde ve ağılarda kullanılan sözcüklerde ve ön seste, iç seste ve son seste gerçekleşmesine göre kategorize edilmiştir. Örneklerin sadece standart dille sınırlı bırakılmaması konuşma dili ve ağıların, alıntı sözcüklerin incelenmiş olması ve art zamanlı incelemelerin yapılması örneklerin çeşitliliğini, konunun anlaşılabilirliğini ve çalışmanın kapsamını arttırmıştır.

Ses Olayları Çözümleme Örnekleri (s. 241-248) başlığında bir sözcükteki ses değişikliklerinin birden fazla ses olayına denk geldiği belirtilmiş ve otuz iki sözcük aşağıdaki ‘hemen' sözcüğünde olduğu gibi ses bilgisi, biçim bilgisi ve köken bilgisi açısından örnek olarak incelenmiştir:

TT hemen < Far. hemān

Sözcükte /-ā-/ ünlüsü /-e-/'ye gelişirken hem kısalmış hem de önlüleşmiştir. Yani, ünlü kısalması ve önlüleşme meydana gelmiştir: $/-\mathrm{e}-/</{ }^{*}-\mathrm{a}-/</-\bar{a}-/$. Söz konusu ses olayları [tam, ilerleyici, uzak] benzeşme temelinde oluşmuş, böylelikle sözcük artllk-önlük uyumuna girmiştir.

Parçalar Üstü Ses Birimleri bölümün son alt başlı̆̆ıdır. Bu başlık altında Vurgu, Süre, Kavşak ve Durak, Ton, Ezgi ve Odaklama kavramları açıklanmış ve verilen örnek cümleler ile pekiştirilmiştir.

Örnekler İçin Taranan Eserler ve Kısaltmaları (s. 271-290) bölümünde ilk üç bölüm hariç diğer bölümlerde yer verilen örnekleri elde etmek için incelenen ve atıf yapılan iki yüz yetmiş yedi eserin bibliyografik künyesine yer verilmiştir.

Kaynaklar (s. 291-296) bölümünde örnekler için incelenen eserler dışında eserin hazırlanışında yararlanılan ve eser içerisinde de atıfta bulunulan yetmiş üç çalışmanın bibliyografik künyesine yer verilmiştir.

İncelenen çalışma, Sunuş ve Kısaltmalar ve İşaretler bölümü ile birlikte Türkiye Türkçesi Ses Bilgisi konusunun ele alındı̆̆ toplam dokuz bölümden oluşmaktadır. Bu bölümler sırasıyla Dil Bilgisi, Ses Bilgisi, Türkçenin Ses Özellikleri, Ses Dizimi, Ses Olayları, Örnekler İçin Taranan Eserler ve Kısaltmaları ile Kaynaklar 


\section{Ј(৫)}

şeklinde başlıklandırılmıştır. Başlıklardan da anlaşıldığı gibi Türkiye Türkçesi Ses Bilgisi konusu incelenirken Dil Bilgisi bölümünden itibaren dilin art zamanlı ve eş zamanlı gelişimi göz önünde bulundurulmuş ve etkileşimde olduğu dillerle karşılaştırılarak genelden özele bir yaklaşımla ele alınmıştır. Standart Türkiye Türkçesinin yanı sıra sözcüklerin konuşma dilindeki ve ağızlardaki kullanımları da incelenmiş ve örneklendirilmiştir. 